\title{
TRADISI MAANTAR PATALIAN PADA PERKAWINAN MASYARAKAT ADAT BANJAR KALIMANTAN SELATAN (TELAAH ANTROPOLOGIS DAN SOSIOLOGIS)
}

\author{
Arie Sulistyoko dan Anwar Hafidzi \\ Fakultas Syariah UIN Antasari Banjarmasin \\ ariesulistyoko51@gmail.com; anwar.hafidzi@uin-antasari.ac.id
}

\section{ABSTRAK}

The marriage in Indonesia is usually done with customary rules, one of which is the Banjar tribe who still has a strong culture in the process of marriage ceremony. In practice in Indonesia, in addition to following religious regulations, tradition also becomes important, as practiced by the people of Banjar when conducting marriages filled with various customs both before, shortly or after marriages are conducted. The application of the procession, the benchmark is honesty itself, where if the total honesty requested is not met by men, then the girl's family prefers to cancel it. In this condition, the local people's customary approach is the benchmark in the traditional Banjar marriage system.

Keywords: Marriage, Maantar; Patalian; Tradition; Banjar

\section{A. PENDAHULUAN}

Islam merangsang orang untuk menikah karena banyak argumen seperti bentuk dorongan. terkadang pernikahan adalah sunnah dari instruksi Nabi kepada mereka yang harus dia ikuti. ${ }^{1}$ Pernikahan adalah bagian dari cara

\footnotetext{
${ }^{1}$ Syaikh Sulaiman Ahmad Yahya Al-Faifi, Ringkasan fikih sunnah Sayyid Sabiq (Jakarta:
} 
hidup yang sangat penting bagi seseorang.

Perkawinan ialah cara terbaik untuk memenuhi sifat manusia, untuk menyampaikan hasrat dan melepaskan hasrat seksual mereka. ${ }^{2}$ Pernikahan adalah cara terbaik untuk melahirkan keturunan, berlipat ganda generasi dan terus hidup dengan merawat mereka yang diperintah oleh Islam. ${ }^{3}$ Ini terkandung dalam kata-kata Nabi Suci, yang berarti: "Dari Anas ibn Malik ra, dia berkata: Utusan Allah (semoga damai besertanya) memerintahkan kita untuk menikah / menikah dan melarang kita untuk tak menikah. Dia berkata : "Menikah dengan wanita yang memiliki banyak anak dan memiliki cinta yang besar, karena saya bangga dengan para Nabi sebelum hari kiamat.". (HR Ahmad dan dishahihkan oleh Ibnu Hibban). ${ }^{4}$

Perkawinan di Indonesia cenderung dilakukan oleh aturan adat, salah satunya adalah suku Banjar yang masih menggunakan budaya dalam hal upacara perkawinan. Dalam praktiknya, selain menaati aturan agama, tradisi juga menjadi penting, seperti yang selalu dipraktikkan oleh masyarakat Banjar ketika melakukan pernikahan yang penuh dengan berbagai kebiasaan baik sebelum, sesaat atau setelah pernikahan dilakukan. Perkawinan orangorang Banjar didasarkan pada pandangan hidup orang-orang Banjar, adalah agama Islam, budaya lokal, dan lingkungan tempat mereka tinggal. Ketiganya telah terintegrasi, jadi jika kita berbicara tentang adat-istiadat pernikahan kita berbicara tentang cara hidup masyarakat Banjar, Kalimantan Selatan, yang telah menjadi pola perilaku, dan perilaku itu selalu diulang.

Pada perkawinan adat Banjar penghormatan terhadap posisi wanita sangatlah besar. Hal ini ditunjukkan dengan acara demi acara yang banyak berpusat di rumah calon mempelai wanita. Dalam sistem perkawinan adat adat Banjar Kalimantan Selatan setelahnya melalui proses lamaran atau disebut Badatang, jika lamaran telah diterima maka pembahasan selanjutnya adalah membahas jumlah jujuran (mas kawin) yang diinginkan oleh keluarga calon istri dan disetujui oleh keluarga calon suami. Dan juga dalam pertemuan ini sekaligus membahas tentang waktu maantar jujuran, pernikahan dan upacara pernikahan. ${ }^{5}$

Pustaka Al-Kautsar, 2013), 402.

2 Faizal Amin, "Sex Education Dalam Paradigma Pendidikan Islam," Tarbiyatuna: Jurnal Pendidikan Islam 9, no. 1 (2016): 78-96.

3 Al-Faifi, Ringkasan fikih sunnah Sayyid Sabiq, 403.

4 Al Hafidz Ibnu Hajar Al-Asqalani, Bulughul Maram Min Adillatil Abkam Alih Bahasa Ahmad Najieh (Semarang: Pustaka Nuun, 2011), 272-273.

5 Gusti Mahfudz, Pola Perkawinan Adat Banjar Di Kalimantan Selatan (Yogyakarta: Lembaga 
Dalam pernikahan tradisional Banjar, penghargaan terhadap posisi perempuan sangat besar. Hal ini ditunjukkan oleh acara demi acara yang banyak berpusat di rumah calon pengantin wanita. Dalam skema perkawinan adat Banjar di Kalimantan Selatan setelah melalui proses lamaran atau disebut Badatang, jika lamaran telah diterima maka selanjutnya membicarakan total jujuran (mas kawin) yang diinginkan oleh keluarga calon istri dan disetujui oleh keluarga calon suami. Selain itu membicarakan tentang waktu jujuran, pernikahan dan upacara pernikahan

Baantar jujuran dalam adat Banjar ialah menandai hadiah, tanda telah menerima salam, di mana maantar jujuran tidak hanya total uang yang diberikan, tetapi disertai dengan persediaan barang-barang penting untuk pengantin wanita biasanya diperlukan oleh pengantin diberikan oleh mempelai laki-laki. ${ }^{6}$ Ihwalnya ialah jujuran lain syarat untuk menikah. Tidak ada yang menuntut jujuran dalam peraturan agama apa pun. Bahkan dalam ajaran Islam, kewajibannya hanya membayar mahar atau mas kawin. Jujuran bukanlah mahar atau mas kawin. Tetapi, budaya yang membalut orang dari generasi ke generasi membangun persepsi bahwa jujuran ialah keharusan yang harus dibayar di samping mahar / mas kawin. Di tradisi Banjar, jujuran ini juga memastikan keberhasilan atau kegagalan pernikahan, dalam hal total tamu yang diundang, makanan yang disajikan, dan lainnya yang terkait dengan upacara pernikahan ${ }^{7}$

Berdasarkan latar belakang di atas tentang tradisi maantar / tradisi jujuran di masyarakat adat Banjar, peneliti tertarik untuk melakukan penelitian pada perspektif masyarakat tentang tradisi ini, apa latar belakang dan tujuan upacara pernikahan dalam melaksanakan tradisi ini. Bagaimana proses adat / memberi jujuran masyarakat adat Banjar dalam tradisi Maantar Patalian / jujuran Masyarakat Adat Banjar

Kependudukan UGM, tt), 18.

${ }^{6}$ Fathurrahman Azhari Zainal Muttaqien Sulaiman Kurdi, "Motivasi Perkawinan Endogami Pada Komunitas Alawiyyin Di Martapura Kabupaten Banjar," Múadalab; Jurnal Studi Gender dan Anak 1, no. 2 (2013); Rifqi Akbari, "Jujuran Dalam Adat Banjar (Kajian Etnografis Hukum Islam Dalam Perkawinan Adat Banjar)" (B.S. thesis, Fakultas Syariah dan Hukum UIN Syarif Hidayatullah Jakarta, n.d.); Mochamad Rochman Firdian, "TRADISI 'MAANTAR JUJURAN' DALAM PERKAWINAN ADAT BANJAR KALIMANTAN SELATAN PERSPEKTIF HUKUM ISLAM" (PhD Thesis, UIN Sunan Ampel Surabaya, 2015).

7 Gusti Muzainah, "BAANTAR JUJURAN DALAM PERKAWINAN ADAT MASYARAKAT BANJAR," Al-Insyiroh: Jurnal Studi Keislaman 5, no. 2 (2019): 10-32. 


\section{B. METODE PENELITIAN}

Metode yang dipakai dalam penelitian ini ialah penelitian deskriptif kualitatif dengan pendekatan fenomenologis rakyat Banjar di Kalimantan Selatan. Teknik pengumpulan data dengan berbagai literatur yang berkaitan dengan penelitian tentang masalah maantar patalian dalam pernikahan. Teknik ini digunakan untuk memahami perihal yang berkaitan dengan orang lain dalam situasi tertentu pada periode sebelum akad pernikahan. ${ }^{8}$

Untuk memperoleh gambar yang berisi cerminan budaya Muslim dalam budaya tradisional pernikahan banjar, beberapa tahapan dilakukan untuk mengumpulkan data. Pada awalnya, pengumpulan data yang luas dan umum tentang hal-hal menarik dilakukan, penting dan berguna untuk diskusi yang lebih dalam. Tahap kedua, penelitian yang dilakukan untuk mengumpulkan data yang dilakukan lebih sesuai dengan fokus penelitian dan memahami sumber data yang kompeten atau informan. Tahap ketiga, penelitian ini melakukan penelitian terfokus, yaitu mengembangkan penelitian eksplorasi untuk penelitian, yaitu tentang masalah refleksi budaya Muslim dalam adat perkawinan adat Banjar.?

\section{TRADISI MASYARAKAT BANJAR DALAM PERNIKAHAN}

Tradisi ialah warisan leluhur yang terus dilakukan sampai sekarang, seperti halnya dengan tradisi maantar jujuran dalam pernikahan adat Banjar yang telah dilakukan sejak sebelum Islam memasuki tanah Banjar. yang telah menjadi kebiasaan di komunitas ini. ${ }^{10}$ Pernikahan dalam Islam ialah satu hal yang perjuangkan oleh agama. Di antara argumen yang menentukan pernikahan ialah dalam Surat Ar-Rum ayat 21:

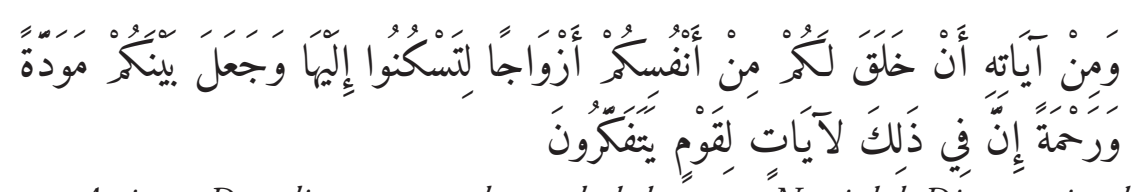

Artinya: Dan di antara tanda-tanda kekuasaan-Nya ialah Dia menciptakan untukmu isteri-isteri dari jenismu sendiri, supaya kamu cenderung dan merasa tenteram kepadanya, dan dijadikan-Nya diantaramu rasa kasih dan sayang. Sesungguhnya pada yang demikian itu benar-benar terdapat tanda-

8 Mariasusai Dhavamony, Fenomenologi Agama (Kanisius, 1995), 43.

9 Dr Rukin M.Si S. Pd, Metodologi Penelitian Kualitatif(Yayasan Ahmar Cendekia Indonesia, n.d.), 88 .

${ }^{10}$ Bungaran Antonius Simanjuntak, Tradisi, Agama, dan Akseptasi Modernisasi Pada Masyarakat Pedesaan Jawa (Edisi Revisi) (Yayasan Pustaka Obor Indonesia, 2016). 
tanda bagi kaum yang berfikir. [QS. Ar-Rum 30:21]

Cara hidup masyarakat Banjar didasarkan pada 3 elemen, yakni Islam, adat setempat dan lingkungannya. Demikian juga dalam adat pernikahan, untuk orang Banjar ketiga elemen ini telah terintegrasi, oleh karena itu jika kita berbicara tentang pernikahan adat kita berbicara tentang integrasi ketiga elemen ini, karena itu adalah pola perilaku, dan perilaku yang terus terjadi berulang kali. ${ }^{11}$ Pernikahan adalah salah satu aspek yang diwarnai oleh adat istiadat yang cukup erat bagi rakyat Banjar.

Bagi rakyat Banjar, proses pernikahan harus dibuat secara rinci. Oleh sebab itu, tak heran prosesi pernikahan memerlukan waktu yang lama dan tidak sedikit biaya. Itu karena budaya orang Banjar kurang lebih dipengaruhi oleh agama Islam yang dibawa oleh pedagang dari Arab pada zaman kuno. Pernikahan dalam hukum adat bukan hanya ikatan antara pria dan wanita sebagai suami dan istri untuk tujuan mendapat keturunan dan memajukan serta menjaga kehidupan keluarga dalam rumah tangga. tetapi itu juga berarti hubungan hukum yang melibatkan anggota keluarga dari suami dan istri. ${ }^{12}$ Dalam tradisi pernikahan di komunitas Banjar, jika ada pria yang ingin menikahi wanita, maka pria itu bertanya pada wanita yang diinginkannya. Pertama keluarga laki-laki bertanya pada keluarga perempuan apakah wanita itu ada yang melamar. Jika tidak ada, maka keluarga pria dapat mengungkapkan niat mereka untuk pergi badatang (melamar).

Dalam pola pernikahan tradisional Banjar, selesai melewati proses Badatang, jika lamaran ini telah diterima maka pembicaraan selanjutnya ialah berbicara tentang total jujuran yang diinginkan oleh keluarga wanita dan disetujui oleh keluarga pria, dan dalam pertemuan ini juga mendiskusikan tentang waktu pernikahan, akad pernikahan, dan upacara pernikahan. ${ }^{13}$ Bagi rakyat Banjar, jujuran ialah salah satu syarat yang harus dipenuhi oleh pria yang ingin menikah. Pada zaman kuno mas kawin atau jujuran pada saat akad pernikahan harus disebutkan secara penuh seperti yang sebelumnya disepakati pada upacara Badatang atau Bapapayuan. Permintaan untuk menyebut

\footnotetext{
${ }^{11}$ Mohamad Idwar Saleh, Adat istiadat dan upacara perkawinan daerah Kalimantan Selatan (Jakarta: Departemen Pendidikan dan Kebudayaan, Direktorat Jenderal Kebudayaan, Direktorat Sejarah dan Nilai Tradisional, Proyek Inventarisasi dan Pembinaan Nilai-Nilai Budaya, 1991), 113.

${ }^{12}$ A. Suriyaman Mustari Pide, Hukum Adat Dabulu, Kini, Dan Akan Datang (Prenada Media, 2017); Ayang Utriza Yakin, Sejarah Hukum Islam Nusantara (Kencana, 2016); Abd Shomad, Hukum Islam: Penormaan Prinsip Syariah dalam Hukum Indonesia (Kencana, 2017).

${ }^{13}$ Mahfudz, Pola Perkawinan Adat Banjar Di Kalimantan Selatan, 3.
} 
jujuran sebagian besar dari laki-laki, karena menyangkut kekuatan status hukum jujuran di masa depan. Ini mengikat permintaan jujuran jika pernikahan gagal, jika kegagalan itu disebabkan oleh seorang wanita yang dalam istilah Banjar "kada bakabaikan" (istri meminta cerai sebelumnya atau tidak ingin diganggu oleh suaminya), maka setengah dari jujuran harus dikembalikan.

Bagi sebagian orang Banjar, tradisi jujuran sebenarnya bukanlah sesuatu yang baru, meskipun tidak ditulis secara tekstual dalam Nash al-quran, tetapi jika kita melihat sejak zaman Nabi Muhammad, ada berbagai aplikasi mas kawin, ini juga alasannya. di belakang komunitas saat menggunakan tradisi ini. ${ }^{14}$

Pada dasarnya, jika dilihat sejarah sejak zaman Nabi, ada seorang teman yang menikah dengan mahar Alquran, selain itu Sayyidina Ali menikah dengan cincin mahar besi dan itu legal di mata agama. Rasulullah Saw menikahi Siti Khadijah dengan mahar 500 unta ditambah sejumlah kambing, ini tidak menunjukkan batasan dan pembatasan pada mahar yang harus diberikan oleh istrinya, yang terpenting ialah bahagia. ${ }^{15}$ Adapun jujuran yang merupakan tradisi sebagai komunitas Banjar, dilihat dari statusnya jika disebutkan dalam akad nikah, statusnya ialah mahar, jika tidak disebut maka hanya hadiah. Bagi orang Banjar, tradisi ini tidak menabrak ajaran Islam, karena jika dipahami nilai-nilai yang terkandung di dalamnya, maka kita akan melihat hubungan yang sesuai dengan ajaran Islam, karena melalui tradisi ini kita akan lebih menghargai wanita yang mau nanti menjadi ibu bagi anakanak anak-anak, itu akan menghargai arti pernikahan, pernikahan ialah hal suci yang harus dijaga.

\section{PEMBERIAN JUJURAN DALAM PRANIKAH}

Budaya identik dengan masalah pranikah. Meskipun beberapa orang

${ }^{14}$ Musa Aripin, Ilmu Hukum IAIN Padangsidimpuan, and A. Pengertian, "Eksistensi Urf Dalam Kompilasi Hukum Islam," Jurnal Al-Maqasid 2, no. 1 (2016); Nasaruddin Umar, Dirjen Bimbingan Masyarakat Islam, and Departemen Agama, "Refleksi Penerapan Hukum Keluarga Di Indonesia," Makalah yang disampaikan pada Konsultasi Nasional Mencapai Hukum Keluarga yang Adil dan Setara Jender diselenggarakan oleh Komnas Perempuan, Jakarta (2009): 3-4.

${ }^{15}$ Syamruddin Nasution, SEJARAH PERKEMBANGAN PERADABAN ISLAM (Asa Riau (CV. Asa Riau), 2017); Novi Indriyani, "Prilaku Bisnis Muhammad Saw. Sebagai Entrepreneur Dalam Filsafat Ekonomi Islam," HUMAN FALAH: Jurnal Ekonomi dan Bisnis Islam 3, no. 1 (2016): 18-33; Evi Indah Fariati, "PERNIKAHAN NABI MUHAMMAD DENGAN MARIA AL-QIBTIYAH” (PhD Thesis, UIN Sunan Ampel Surabaya, 2015). 
tidak terlalu mempermasalahkannya. ${ }^{16}$ Pada prinsipnya, dengan pría atau dapat juga disiapkan oleh orang tua dari pria yang diberikan kepada wanita, tetapi tidak diberikan kepada pengantin wanita, tetapi digunakan untuk tujuan membiayai kebutuhan satu set pernikahan.. ${ }^{17}$ Setiap individu ketika melaksanakan sesuatu, selain memiliki alasan dasar mereka melakukannya, tentu saja memiliki tujuan dan niat yang berbeda, dan bagi orang Banjar dalam menjalankan tradisi maantar dalam pernikahan tradisional Banjar, mereka memiliki kesadaran dan tujuan yang beragam.

Sebenarnya yang ideal untuk menentukan bukanlah melihat total masyarakat sekitar, tetapi hasil diskusi antara kedua belah pihak keluarga harus menjadi tolok ukur untuk jumlahnya, karena kemampuan seseorang untuk bervariasi jumlahnya. Namun dalam kenyataannya status sosial juga tidak dapat dihindari di beberapa masyarakat dengan mengekspresikan gengsi dan keegoisan. Selain itu, masyarakat menganggap bahwa tradisi Maantar adalah salah satu identitas dan karakteristik masyarakat Banjar, oleh karena itu sudah menjadi kewajiban bagi mereka untuk melestarikan tradisi tersebut.

Uang jujur dalam perkawinan komunitas Banjar mengandung setidaknya tiga tujuan, yaitu: ${ }^{18}$

Pertama: Dalam hal posisi, adalah pilar pernikahan di masyarakat Banjar. Kedua: Dalam hal fungsi, uang adalah hadiah yang diberikan dari pesta pría kepada wanita sebagai biaya resepsi pernikahan dan penyediaan kehidupan kemudian untuk tinggal di rumah tangga.

Ketiga: Dalam hal tujuan, uang jujur adalah untuk memberikan prestise (tanda kehormatan) bagi wanita jika jumlah yang ditetapkan dapat dipenuhi oleh pria.

${ }^{16}$ Rizqi Maulida Amalia and Muhammad Yudi Ali Akbar, "Konseling Islam Perannya Bagi Pemilihan Pasangan Dan Kesiapan Pernikahan," JURKAM: Jurnal Konseling Andi Matappa 1, no. 2 (2017): 125-130; Khoirul Anam, "Analisis Al-Maslahah al-Mursalah Terhadap Program Sekolah Pra Nikah Oleh Pusat Pembelajaran Keluarga (PUSPAGA) Di Surabaya” (PhD Thesis, UIN Sunan Ampel Surabaya, 2019).

17 Anwar Hafidzi, "Penolakan Nasab Anak Li'an Dan Dhihar Dengan Ta’liq (Analisis Komparatif Naskah Kitab Fiqh al-Islam Wa Adillatuhu Dengan al-Mughni)," Ulul Albab: Jurnal Studi dan Penelitian Hukum Islam 1, no. 2 (2018): 77-94; Anwar Hafidzi and Eka Hayatunnisa, "Kriteria Poligami Serta Dampaknya Melalui Pendekatan Alla Tuqsitu Fi Al-Yatama Dalam Kitab Fikih Islam Wa Adillatuhu," Syariah: Jurnal Hukum dan Pemikiran 17, no. 1 (2017).

${ }^{18}$ Efentinus Ndruru, "Perempuan Dan Adat Perkawinan (Studi Tentang Marginalisasi Perempuan Dalam Jujuran Adat Istiadat Perkawinan Di Nias)," Jurnal Community 3, no. 1 (2018); Muzainah, "BAANTAR JUJURAN DALAM PERKAWINAN ADAT MASYARAKAT BANJAR"; Akbari, "Jujuran Dalam Adat Banjar (Kajian Etnografis Hukum Islam Dalam Perkawinan Adat Banjar).” 
Di masa lalu semua jumlah yang disepakati di acara Badatang atau Basasuluh disebutkan ketika persetujuan diberikan, sehingga mirip dengan posisi mahar dalam Islam yang memiliki kekuatan di mata hukum Islam dan Hukum Positif, ini berkaitan dengan pengembalian atau mas kawin jika perkawinan atau kegagalan terjadi, maka istri meminta cerai sebelum suaminya turun tangan. Di komunitas Banjar, misalnya, bahwa pesta pernikahan didanai oleh pria dan karena jumlah uang yang kecil, jumlah undangan juga kecil, karena wanita tidak ingin memberikan terlalu banyak biaya tambahan untuk pernikahan.

Di masa lalu masyarakat ketika perjanjian tentang jumlah upacara Badatangatau Bapapayuan dilakukan dengan mediayang ditutupi dengan kain dan kemudian diserahkan kepada para wanita, serta para wanita membalas dan menawar tanpa menggunakan kata-kata sampai akhirnya menemukan sebuah persetujuan sebelum dibuka dan diberitahukan kepada keluarga dan kerabat yang hadir. Itu karena di masa lalu mereka masih menggunakan koin yang mudah dihitung, dan masing-masing pihak saling menghormati hak privasi masing-masing karena hal ini melibatkan martabat keluarga. Adapun apa yang terjadi di masa lalu, proses perjanjian dilakukan dengan dialog langsung antara kedua belah pihak keluarga tanpa menggunakan uang media secara langsung seperti yang dilakukan di zaman kuno. Hal ini disebabkan perkembangan zaman ditambah sekarang bahwa jumlahnya telah menjadi rahasia umum, yang berarti bahwa itu bukan sesuatu privasi yang berbeda dari masa lalu.

Namun, beberapa pria yang menikahi wanita dari komunitas Banjar tidak merasa terbebani oleh nilai uang yang relatif tinggi karena dalam menentukan proses tawar-menawar terjadi terlebih dahulu hingga tercapai kesepakatan sehingga masih dalam batas kemampuan pria. bertemu. Selama masa ini para pria juga tahu sebelumnya tentang adat-istiadat ini sehingga mereka telah mempersiapkan segalanya sebelum melangkah ke tingkat yang lebih serius. Uang itu sendiri akan digunakan untuk membiayai penyelenggaraan pernikahan, membeli perabot rumah tangga, barang-barang yang dibutuhkan untuk pasangan yang baru menikah, yang semuanya dikembalikan untuk kepentingan mereka yang akan menjalani kehidupan baru. Karena biasanya setelah mereka menikah, mempelai laki-laki tinggal di sebuah rumah di mana pengantin wanita dapat selama mereka dapat memiliki rumah mereka sendiri. Jadi persiapan yang lengkap diperlukan di rumah orang tua pengantin wanita yang sebagian didanai. 


\section{E. HUBUNGAN TRADISI JUJURAN DAN PEMBERIAN HAK WANITA}

Upacara Maantar Jujuran dalam pernikahan tradisional Banjar telah mulai dilakukan berulang kali dan diintegrasikan ke dalam kehidupan masyarakat Banjar, sehingga menjadi ciri khas dalam pernikahan tradisional suku Banjar. Karena itu, perasaan tidak nyaman muncul secara alami ketika orang Banjar meninggalkan salah satu tradisi ini, termasuk tradisi kejujuran maantar. Bagi orang Banjar ketika menjalankan tradisi ini mereka merasakan manfaat untuk kehidupan nyata mereka seperti, manfaat bagi kehidupan pengantin wanita dalam membangun rumah tangga, hubungan antara dua keluarga pengantin wanita semakin dekat, dan sebagainya, yang tidak ditemukan jika mereka tidak menjalankan tradisi ini

Tradisi Maantar adalah tradisi yang menjadi sorotan masyarakat karena upacara ini akan dihadiri oleh keluarga besar, saudara dan tetangga. Setelah mendapat persetujuan antara kedua keluarga pada upacara sebelumnya Badatang dan Bapapayuan mengenai jumlah dan barang-barang seperti pakaian wanita secara penuh dan sebagainya, maka upacara Maantar (mengirim) jujuran (mas kawin). Ketika datang ke kondisi tentang jujuran, tidak ada aturan yang pasti. Namun, biasanya apa yang terjadi pada masyarakat adat Banjar harus melalui proses diskusi yang terjadi ketika ada kesepakatan atau apa yang disebut 'harmoni' antara kedua pihak dari kedua keluarga pengantin wanita. Perjanjian ini mencakup jumlah nilai jujuran dan waktu pemberian hadiah. Biasanya keputusan untuk melanjutkan atau tidak rencana pernikahan terjadi saat ini. Kemudian jumlah jujuran dapat dipahami dalam arti sesuai dengan kemampuan pria dengan persetujuan dan kehendak wanita dan keluarga mereka.

Penyerahan mas kawin atau jujuran adalah tanda bahwa pria menginginkan pernikahan dilakukan dengan cepat. Prosesi Maantar Jujuran adalah satu kesatuan dari semua tahapan proses pernikahan di antara orang banjar yang biasanya didahului oleh pria yang datang ke wanita untuk melakukan proposal atau dikenal sebagai basasuluh. Dalam proses aplikasi ini, jika wanita itu tahu siapa calon pelamar untuk putrinya dan tampaknya tidak menyenangkan keluarga gadis itu, maka mereka mencoba untuk menolaknya secara halus, dengan mengatakan bahwa putrinya bertunangan, masih kecil atau masih ingin melanjutkan pendidikannya atau terkadang dengan membayangkan (menentukan) jujuran yang sangat tinggi. ${ }^{19}$

\footnotetext{
${ }^{19}$ Alfani Daud, Islam dan masyarakat Banjar: deskripsi dan analisa kebudayaan Banjar, 1990,
} 
Proses maantar jujuran dimulai dengan balasan oleh perwakilan dari juru bicara pengantin. Acara petalian ini lebih bersifat seremonial dan selalu mengundang banyak orang. Dalam acara ini, biasanya acara khusus untuk ibu-ibu, dari menyerahkan mahar ke menyerahkan pangiring atau peralatan yang cukup untuk calon pengantin dalam bentuk peralatan dari kepala sampai kaki. Gelas / mangkuk hias telah disiapkan untuk menyimpan uang jujuran, dan mangkuk biasa ialah tempat untuk meletakkan nasi kuning atau kunyit dan daun bunga rampai atau pandan dan sering dicampur dengan mawar atau daun melati dan ditaburi dengan air mawar. Jangan lewatkan bagian pucuk pisang, jamu, dan bamban. Untuk menerima jujuran dan barang-barang lainnya yang dibawa oleh delegasi sarjana, karpet biasanya disiapkan dan didekorasi dengan indah. Dalam upacara ini, sangat jelas bahwa tradisi mendominasi rangkaian upacara, di samping implementasi unsur-unsur ajaran Islam.

Tanda-tanda keterlibatan atau komitmen adalah dalam bentuk peralatan wanita, termasuk; sarung, pakaian, tudung, bra, sandal, galung, makeup dan benda-benda lainnya untuk wanita yang diusulkan. Biasanya pakaian yang diserahkan ketiganya, artinya setiap jenis pakaian atau peralatan yang diserahkan masing-masing berjumlah tiga potong / lembar. Dalam perkembangan budaya saat ini, kadang-kadang acara pertukaran cincin juga dimasukkan. Upacara maatar patalian dimulai dengan kata-kata pembuka dari pemimpin upacara, dimulai dengan membaca bismillah atau al fatihah, kemudian membaca pengaturan program. Setelah itu kesempatan diberikan kepada para ibu dari keluarga laki-laki, untuk memberikan satu atau dua kata sebagai percakapan pembuka. Tugas ini biasanya dilakukan oleh seorang ibu yang secara khusus ditugaskan untuk menyampaikan pidato. Pidato untuk tujuan kedatangan dibumbui dengan pantun. Contoh sajak, seperti: "Batang Sambal bukan batang, batang durian kita. Tidak datang sekarang, datang kita meledak jujurannya". Jika pihak laki-laki telah selesai menyampaikan pidato, maka oleh penyelenggara acara, kesempatan untuk memberikan balasan diberikan kepada ibu-ibu dari keluarga perempuan, juga diwakili oleh seorang ibu yang bertugas menanggapi pidato dengan kata-kata yang dibumbui oleh pantun juga. Setelah sambutan dan balasan dari kedua belah pihak, upacara serah terima diadakan sebagai tanda pertunangan.

Peristiwa patalian atau baantar jujuran biasanya kelompok lelaki membawa peralatan serba untuk calon pengantin mulai dari sepatu, sandal, pakaian, tas, perlengkapan mandi, pakaian dalam dan lain-lain, dalam hal

75. 
uang dari jujuran dikirim langsung dan tidak ketinggalan ada beras kuning, rampah dimasak dan ruas bamban. Jarak upacara patalian biasanya tidak terlalu jauh, bisa satu minggu, satu bulan, beberapa bulan, atau dilaksanakan pada hari yang sama, tidak ada ketentuan khusus mengenai hal ini, tergantung kesepakatan dari kedua belah pihak mempelai.

Total jujuran tergantung pada kemampuan mempelai laki-laki untuk menggunakan uang itu untuk melaksanakan pernikahan. Selain uang, pengantin pria biasanya menawarkan barang-barang dalam bentuk kebutuhan pribadi wanita. Pada dasarnya, mempelai laki-laki dipersiapkan oleh calon mempelai laki-laki, calon mempelai pria sendiri dipersiapkan atau disiapkan oleh orang tuanya dan bahkan dapat dipersiapkan bersama oleh kerabat dekatnya jika uang untuk kejujuran tidak cukup. Dalam perkembangannya saat upacara maantar patalian sering juga ditambah dengan upacara maantar jujuran atau manaikakan jujuran, ialah penyerahan uang tunai. Dengan penyerahan uang jujuran, maka secara tidak langsung keluarga lelaki yang melamar menginginkan upacara pernikahan dilaksanakan sesegera mungkin.

Ketika menyerahkan uang jujur, ada modifikasi di tempat uang jujur. Ini dengan demikian telah menggeser makna wadah uang kejujuran. Awalnya menurut adat, uang jujur yang diberikan oleh calon pengantin pria kepada calon pengantin, dimasukkan ke dalam keranjang (wadah yang terbuat dari purun) yang biasanya digunakan untuk mencuci beras. Keranjang itu diisi dengan nasi kuning dan bunga rampai, kemudian diaduk dengan perancah (sendok nasi) sehingga uang dan nasi kuning serta bunga rampai menyatu. Selanjutnya uang diambil dan jumlahnya dihitung di depan undangan yang hadir. Jika jumlah uang sesuai dengan kesepakatan awal, maka uang itu dimasukkan kembali ke keranjang dan diserahkan kepada orang tua pengantin wanita. Koleksi dan uang kejujuran, maka harus disimpan dalam toples selama tiga hari tiga malam. Ini berarti bahwa calon pengantin akan hidup dingin (hidup rahuh rahayu, terlihat beruntung dan bahagia). Selain memasukkan uang jujur ke keranjang, ada juga yang memasukkannya ke dalam buah kelapa yang isinya sudah dibuang. Kelapa yang berisi uang kejujuran ditempatkan di panginangan (mangkuk). Dalam lilin yang diisi dengan kelapa, uang itu dinyalakan dengan lilin, kemudian dibawa oleh beberapa orang, terutama ibu dan anak perempuan (diarak) ke rumah pengantin wanita, untuk diserahkan sebagai mahar. Oleh pengantin wanita, kejujuran diadakan selama tiga hari tiga malam. Setelah waktu itu, uang yang jujur diambil oleh mempelai lakilaki, dan hanya sebagian kecil yang tersisa sebagai jaminan. Uang yang jujur dikembalikan lagi ke pengantin wanita, dengan cara mencicil sedikit demi 
sedikit hingga terbayar. Dengan pembayaran kembali uang jujur, itu berarti upacara pernikahan dapat diadakan. Upacara patalian dan upacara kejujuran berakhir dengan mencicipi hidangan dalam bentuk kue bingka, alua-maalua (permen), roti, martabak, ketan, dan makanan lainnya. Di masa lalu, barangbarang ini diserahkan ketika acara Bapapayuan berarti bahwa mereka dimasukkan dengan patalat sebagai tanda, tetapi sekarang tradisi ini telah menjadi upacara yang cukup hidup dengan mengundang keluarga, kerabat, dan orangorang. Ini juga berfungsi sebagai pengumuman bahwa dia akan segera menikah. ${ }^{20}$

\section{F. PENUTUP}

Berdasarkan uraian di atas, dapat disimpulkan bahwa penerapan analisis dari pendekatan sosiologis adalah bahwa tolok ukurnya adalah kejujuran itu sendiri, di mana jika total jujuran yang diminta oleh gadis itu dan keluarga gadis itu tidak dapat dipenuhi oleh pria itu, maka kebanyakan pihak gadis itu lebih memilih untuk membatalkan atau tidak melanjutkan proses pernikahan jika ini terjadi kondisi pria yang melamar adalah orang asing. Saat ini, melalui pendekatan antropologis ternyata ini tidak sepenuhnya berlaku untuk setiap keluarga sebelum menikah dan masih ada tawar-menawar dan toleransi dalam menyetujui jumlah uang jujuran berdasarkan adat yang berlaku di desa atau tempat tertentu.

${ }^{20}$ Saleh, Adat istiadat dan upacara perkawinan daerah Kalimantan Selatan, 51. 


\section{DAFTAR PUSTAKA}

Akbari, Rifqi. "Jujuran Dalam Adat Banjar (Kajian Etnografis Hukum Islam Dalam Perkawinan Adat Banjar).” B.S. thesis, Fakultas Syariah dan Hukum UIN Syarif Hidayatullah Jakarta, n.d.

Al-Asqalani, Al Hafidz Ibnu Hajar. Bulughul Maram Min Adillatil Abkam Alih Bahasa Ahmad Najieh. Semarang: Pustaka Nuun, 2011.

Al-Faifi, Syaikh Sulaiman Ahmad Yahya. Ringkasan fikih sunnab Sayyid Sabiq. Jakarta: Pustaka Al-Kautsar, 2013.

Amalia, Rizqi Maulida, and Muhammad Yudi Ali Akbar. "Konseling Islam Perannya Bagi Pemilihan Pasangan Dan Kesiapan Pernikahan." JURKAM: Jurnal Konseling Andi Matappa 1, no. 2 (2017): 125-130.

Amin, Faizal. "Sex Education Dalam Paradigma Pendidikan Islam." Tarbiyatuna: Jurnal Pendidikan Islam 9, no. 1 (2016): 78-96.

Anam, Khoirul. "Analisis Al-Maslahah al-Mursalah Terhadap Program Sekolah Pra Nikah Oleh Pusat Pembelajaran Keluarga (PUSPAGA)

Di Surabaya." PhD Thesis, UIN Sunan Ampel Surabaya, 2019.

Aripin, Musa, Ilmu Hukum IAIN Padangsidimpuan, and A. Pengertian. "Eksistensi Urf Dalam Kompilasi Hukum Islam." Jurnal Al-Maqasid 2, no. 1 (2016).

Daud, Alfani. Islam dan masyarakat Banjar: deskripsi dan analisa kebudayaan Banjar, 1990.

Dhavamony, Mariasusai. Fenomenologi Agama. Kanisius, 1995.

Fariati, Evi Indah. "PERNIKAHAN NABI MUHAMMAD DENGAN MARIA AL-QIBTIYAH." PhD Thesis, UIN Sunan Ampel Surabaya, 2015.

Firdian, Mochamad Rochman. "TRADISI 'MAANTAR JUJURAN' DALAM PERKAWINAN ADAT BANJAR KALIMANTAN SELATAN PERSPEKTIF HUKUM ISLAM." PhD Thesis, UIN Sunan Ampel Surabaya, 2015.

Hafidzi, Anwar. "Penolakan Nasab Anak Li'an Dan Dhihar Dengan Ta'liq (Analisis Komparatif Naskah Kitab Fiqh al-Islam Wa Adillatuhu Dengan al-Mughni)." Ulul Albab:Jurnal Studi dan Penelitian Hukum Islam 1, no. 2 (2018): 77-94.

Hafidzi, Anwar, and Eka Hayatunnisa. "Kriteria Poligami Serta Dampaknya Melalui Pendekatan Alla Tuqsitu Fi Al-Yatama Dalam Kitab Fikih Islam Wa Adillatuhu." Syariah: Jurnal Hukum dan Pemikiran 17, no. 1 (2017). 
Indriyani, Novi. "Prilaku Bisnis Muhammad Saw. Sebagai Entrepreneur Dalam Filsafat Ekonomi Islam." HUMAN FALAH: Jurnal Ekonomi dan Bisnis Islam 3, no. 1 (2016): 18-33.

Kurdi, Fathurrahman Azhari Zainal Muttaqien Sulaiman. "Motivasi Perkawinan Endogami Pada Komunitas Alawiyyin Di Martapura Kabupaten Banjar." Múadalah; Jurnal Studi Gender dan Anak 1, no. 2 (2013).

Mahfudz, Gusti. Pola Perkawinan Adat Banjar Di Kalimantan Selatan. Yogyakarta: Lembaga Kependudukan UGM, tt.

M.Si, Dr Rukin, S. Pd. Metodologi Penelitian Kualitatif. Yayasan Ahmar Cendekia Indonesia, n.d.

Muzainah, Gusti. "BAANTAR JUJURAN DALAM PERKAWINAN ADAT MASYARAKAT BANJAR.” Al-Insyiroh: Jurnal Studi Keislaman 5, no. 2 (2019): 10-32.

Nasution, Syamruddin. SEJARAH PERKEMBANGAN PERADABAN ISLAM. Asa Riau (CV. Asa Riau), 2017.

Ndruru, Efentinus. "Perempuan Dan Adat Perkawinan (Studi Tentang Marginalisasi Perempuan Dalam Jujuran Adat Istiadat Perkawinan Di Nias)." Jurnal Community 3, no. 1 (2018).

Pide, A. Suriyaman Mustari. Hukum Adat Dabulu, Kini, Dan Akan Datang. Prenada Media, 2017.

Saleh, Mohamad Idwar. Adat istiadat dan upacara perkawinan daerah Kalimantan Selatan. Jakarta: Departemen Pendidikan dan Kebudayaan, Direktorat Jenderal Kebudayaan, Direktorat Sejarah dan Nilai Tradisional, Proyek Inventarisasi dan Pembinaan NilaiNilai Budaya, 1991.

Shomad, Abd. Hukum Islam: Penormaan Prinsip Syariah dalam Hukum Indonesia. Kencana, 2017.

Simanjuntak, Bungaran Antonius. Tradisi, Agama, dan Akseptasi Modernisasi Pada Masyarakat Pedesaan Jawa (Edisi Revisi). Yayasan Pustaka Obor Indonesia, 2016.

Umar, Nasaruddin, Dirjen Bimbingan Masyarakat Islam, and Departemen Agama. "Refleksi Penerapan Hukum Keluarga Di Indonesia." Makalah yang disampaikan pada Konsultasi Nasional Mencapai Hukum Keluarga yang Adil dan Setara Jender diselenggarakan oleh Komnas Perempuan, Jakarta (2009): 3-4.

Yakin, Ayang Utriza. Sejarah Hukum Islam Nusantara. Kencana, 2016. 